\title{
Imagining the world: the significance of religious worldviews for science education
}

\author{
MICHAEL J. REISS
}

Institute of Education, University of London, 20 Bedford Way, London WC1H 0AL, UK. email:m.reiss@ioe.ac.uk

\begin{abstract}
This paper begins by examining whether 'science' and 'religion' can better be seen as distinct or related worldviews, focusing particularly on scientific and religious understandings of biodiversity. I then explore how people can see the natural world, depending on their worldview, by looking at two contrasting treatments of penguin behaviour, namely that provided in the film March of the Penguins and in the children's book And Tango Makes Three. I end by drawing some initial conclusions as to what might and what might not be included about religion in school science lessons. Science educators and teachers need to take account of religious worldviews if some students are better to understand the compass of scientific thinking and some of science's key conclusions. It is perfectly possible for a science teacher to be respectful of the worldviews that students occupy, even if these are scientifically limited, while clearly and non-apologetically helping them to understand the scientific worldview on a particular issue.
\end{abstract}

What it will be Questioned When the Sun rises do you not see a round Disk of fire somewhat like a Guinea $\mathrm{O}$ no no I see an Innumerable company of the Heavenly host crying Holy Holy Holy is the Lord God Almighty.

(Blake, 1810)

For many science educators, whether or not they have any religious beliefs themselves, the relationship between science and religion, i.e. what is sometimes referred to as the 'science/religion issue', may appear somewhat outside the scope of science education. However, a range of factors suggests that this perspective may be too narrow. These factors include a greater awareness of the benefits of dealing explicitly in the school classroom with the nature of science (Osborne et al., 2003; Lederman, 2007) and, more particularly, the increasing significance of creationism and intelligent design in a number of countries (Dembski, 1999; Ayala, 2006; Edis, 2007; Jones \& Reiss, 2007), particularly, but not just, the USA. 
In this article I attempt to do three things. First, to examine whether 'science' and 'religion' can better be seen, for the purposes of school science education, as distinct or related worldviews, focusing particularly on scientific and religious understandings of biodiversity. Secondly, to explore the ways in which people can see (imagine, read) the natural world in a certain way, depending on their worldview, by looking at two contrasting treatments of penguin behaviour. Thirdly, to draw some initial conclusions as to what might and what might not be included about religion in school science lessons. My central argument is that substantial numbers of people, including school students, view the natural world in ways that differs greatly from the standard account presented in school science textbooks and lessons, and in ways that traditional conceptions of 'scientific misconceptions' cannot address. Unless science teachers take account of this, school science will fail to enable students to learn much of these areas of science at more than a superficial level or to engage students with science.

\section{The relationship between science and religion}

There is a large and growing literature on the relationship between science and religion. An extensive treatment of the issue is beyond the scope of this paper as one would need first to review what is meant by science and then what is meant by religion (many books, of course, have been written on each question) before beginning to examine the relationship between the two. The whole issue is compounded by the argument of Brooke (1991) that:

There is no such thing as the relationship between science and religion. It is what different individuals and communities have made of it in a plethora of different contexts. Not only has the problematic interface between them shifted over time, but there is also a high degree of artificiality in abstracting the science and the religion of earlier centuries to see how they were related.

(Brooke, 1991, page 321)

Brooke's argument is an empirical one, informed by detailed study of historical instances of the relationship between science (principally Western science) and religion (principally one or more of the branches of Christianity). A valuable 
categorisation of the range of ways in which the relationship(s) between science and religion can be understood is provided by Barbour (1990). Barbour, who focuses especially on epistemological assumptions of recent Western authors, identifies four main groupings (Reiss, in press).

First, there is the relationship of conflict. I write 'first' because it is the first in Barbour's list; it is also first in the minds of some modernists who do not have a religious faith (e.g. Dawkins, 2006). Barbour doesn't give reasons for the order of his listing but at least two can be suggested: comprehensibility and familiarity. It is both straightforward and familiar (given Barbour's declared focus on recent Western authors) to see the relationship between science and religion as one of conflict. As, though, one might expect from a professor of science, technology and society, Barbour sees limitations in this way of understanding the science/religion issue. As he evocably puts it:

In a fight between a boa constrictor and a wart-hog, the victor, whichever it is, swallows the vanquished. In scientific materialism, science swallows religion. In biblical literalism, religion swallows science. The fight can be avoided if they occupy separate territories or if, as I will suggest, they each pursue more appropriate diets.

(Barbour, 1990, page 4)

Barbour's second grouping is independence, a relationship strongly defended by Gould (1999). Science and religion may be seen as independent for a number of reasons: because they use distinctive methods, because they ask different questions, or because they function as different languages. In any event, the result is that each is seen as distinct from the other and enjoys its own autonomy.

Barbour's third grouping moves beyond conflict and independence to dialogue (e.g. Watts, 1998; Williams, 2001; Polkinghorne, 2005). As an example of dialogue, Barbour points out how our understanding of astronomy has forced us to ask why the initial conditions were present that allowed the universe to evolve, a question that has given rise to the anthropic principle, reflection on matters scientific by some theologians and reflection on matters theological by some scientists (cf. Rees, 2003; Collins, 2006). The point is not that the findings of science require a religious faith that would be for the wart-hog of religion to devour the boa constrictor of science. Rather, the point is that scientific advances can give rise (no claim is made that they 
do for all people) to religious questions, so that a dialogue results.

Barbour's final grouping is one in which the relationship between science and religion is seen to be one of integration (cf. Polkinghorne, 1994; Peacocke, 2001). For example, in natural theology it is held that the existence of God or, at any rate, an appreciation of some of God's attributes, can be deduced from aspects of nature rather than from revelation or religious experience (e.g. Ray, 1691/2005; Reiss, 1993). Natural theology has rather fallen out of favour. A more modern approach is process theology which rejects a view of the world in which purely natural events (characterised by an absence of divine activity) are punctuated by occasional instances where God acts supernaturally. Rather, for process theologians, every event is understood "to be jointly the product of the entity's past, its own action, and the action of God" (Barbour, 1990, page 29). Furthermore, God is not the Unmoved Mover of Thomas Aquinas but instead acts reciprocally with the world.

Of course, Barbour's categorisation is not the only one. Haught (1995) identifies the conflict position, the contrast approach, the contact approach and a fourth understanding, which:

emphasizes the subtle but significant ways in which religion positively supports the scientific adventure of discovery. It looks for those ways in which religion, without in any way interfering with science, paves the way for some of its ideas, and even gives a special kind of blessing, or what I call confirmation, to the scientific quest for truth.

(Haught, 1995, page 4)

It is clear that the ways in which the relationship between science and religion is understood have changed over the years, depend on the religion in question and remain fluid (see also Al-Hayani, 2005; Szerszynski, 2005). Nevertheless, at the risk of oversimplifying, there are perhaps two key issues. One is to do with understandings of reality; the other to do with the nature of evidence and authority (Reiss, in press). Most religions hold that reality consists of more than the objective world and many religions give weight to personal and/or (depending on the religion) institutional authority in a way that science generally strives not to. For example, there is a very large religious and theological literature on the world to come, i.e. after death, (e.g. Hick, 1976/1985). However, science, strictly speaking, has little or (I would hold) nothing to say about this question which is to do with the nature of reality. Equally, 
with regard to the nature of authority, many religious believers are likely to consider the recorded pronouncements of their religion's founder(s) to be worth believing even if they seem contradicted by empirical evidence.

\section{Scientific and religious understandings of biodiversity}

The scientific understanding of biodiversity is far from complete but the narrative is a powerful one. Around 3.5 billion years ago, life evolved on Earth. Very little is known with any great confidence about this early history (Maynard Smith \& Szathmary, 2000), far less than is known, for example, about how stars form, grow and die. By the time of the earliest fossils, life was unicellular and bacteria-like. Fastforwarding considerably, natural selection, possibly aided by other mechanisms (genetic drift, etc.), eventually resulted in the 10 million or so species, including our own, that we find today.

For our purposes, the key point is that the scientific worldview is materialistic in the sense that it is neither idealistic nor admits of non-physical explanations (here, 'physical' includes such things as energy and the curvature of space as well as matter). There is much that remains unknown. How did the earliest self-replicating molecules arise? What caused membranes to exist? How key were the earliest physical conditions - temperature, the occurrence of water and so forth? But the scientific presumption is either that these questions will be answered by science or that they will remain unknown. Although some scientists might (sometimes grudgingly) admit that science cannot disprove supernatural explanations, scientists do not employ such explanations in their work (the tiny handful of seeming exceptions only attest to the strength of the general rule).

Religious understandings of biodiversity are more diverse. Many religious believers are perfectly comfortable with the scientific understanding, either on its own or accompanied by a belief that evolution in some sense takes place within God's holding (compass or care), whether or not God is presumed to have intervened or acted providentially at certain key points (e.g. the origin of life or the evolution of humanity). But many other religious believers adopt a more creationist perspective. Creationism exists in a number of different versions but about $40 \%$ of adults in the USA and over $10 \%$ in the UK believe that the Earth is only some 10,000 years old, that it came into existence as described in the early parts of the Bible or the Qu'ran 
and that the most that evolution has done is to change species into closely related species (Miller et al., 2006). For a creationist it is perfectly possible that the various species of gazelle had a common ancestor but this is not the case for gazelles, bears and squirrels - still less for monkeys and humans, for birds and reptiles or for fish and fir trees.

Allied to creationism is the theory of intelligent design. While many of those who advocate intelligent design have been involved in the creationism movement, to the extent that the US courts have argued that the country's First Amendment separation of religion and the State precludes its teaching in public schools (Moore, 2007), intelligent design can claim to be a theory that simply critiques evolutionary biology rather than advocating or requiring religious faith. Those who promote intelligent design typically come from a conservative faith-based position. However, in many of their arguments, they make no reference to the scriptures or a deity but argue that the intricacy of what we see in the natural world, including at a sub-cellular level, provides strong evidence for the existence of an intelligence behind this (e.g. Behe, 1996; Dembski, 1998; Johnson, 1999). An undirected process, such as natural selection, is held to be inadequate.

Most of the literature on creationism (and/or intelligent design) and evolutionary theory puts them in stark opposition. Evolution is consistently presented in creationist books and articles as illogical (e.g. natural selection cannot, on account of the second law of thermodynamics, create order out of disorder; mutations are always deleterious and so cannot lead to improvements), contradicted by the scientific evidence (e.g. the fossil record shows human footprints alongside animals supposed by evolutionists to be long extinct; the fossil record does not provide evidence for transitional forms), the product of non-scientific reasoning (e.g. the early history of life would require life to arise from inorganic matter - a form of spontaneous generation rejected by science in the $19^{\text {th }}$ Century; radioactive dating makes assumptions about the constancy of natural processes over aeons of time whereas we increasingly know of natural processes that affect the rate of radioactive decay), the product of those who ridicule the word of God, and a cause of a whole range of social evils (from eugenics, Marxism, Nazism and racism to juvenile delinquency) - e.g. Whitcomb \& Morris (1961), Watson (1975), Hayward (1985), Baker (2003), Parker (2006) and articles too many to mention in the journals and other publications of such organisations as Answers in Genesis, the Biblical Creation Society, the Creation 
Science Movement and the Institute for Creation Research.

By and large, creationism has received similarly short shrift from those who accept the theory of evolution. In a fairly early study the philosopher of science Philip Kitcher argued that "in attacking the methods of evolutionary biology, Creationists are actually criticizing methods that are used throughout science" (Kitcher, 1982, pages 4-5). Kitcher concluded that the flat-earth theory, the chemistry of the four elements, and mediaeval astrology "have just as much claim to rival current scientific views as Creationism does to challenge evolutionary biology" (Kitcher, 1982, page 5). An even more trenchant attack on creationism is provided by geologist Ian Plimmer whose book title Telling Lies for God: Reason vs Creationism (Plimmer, 1994) indicates the line he takes.

Many scientists have defended evolutionary biology from creationism - see, for example, the various contributions in Selkirk \& Burrows (1987), Good et al. (1992) and Jones \& Reiss (2007) and an increasing number of agreed statements by scientists on the teaching of evolution (e.g. Interacademy Panel on International Issues, 2006). The main points that are frequently made are that evolutionary biology is good science since not all science consists of controlled experiments where the results can be collected within a short period of time; that creationism (including 'scientific creationism') isn't really a science in that its ultimate authority is scriptural and theological rather than the evidence obtained from the natural world; and that an acceptance of evolution is fully compatible with a religious faith, an assertion most often made in relation to Christianity (e.g. Southgate et al., 2005) whilst more obviously true of many other religions - including Hinduism, Buddhism and Judaism - and probably rather less true of Islam (Mabud, 1991; Negus, 2005; Edis, 2007).

\section{March of the Penguins}

March of the Penguins is a stunning 2005 National Geographic feature film. It runs for approximately 85 minutes, has a ' $U$ ' (Universal) certificate (i.e. is deemed to be 'Suitable for all' though, according to the back of the DVD casing, it 'Contains mild peril') and is accompanied by a beautiful coffee table book available in the original 2005 French and a 2006 translation into English (Jacquet, 2006). For a photo gallery, downloads, a trailer, desktops, a screensaver and buddy icons see the official website (Warner Independent Pictures, 2006) which gives a good impression of the 
exceptional footage in the full length film. The website also starts with the words of Morgan Freeman that begin the English (USA) film: "In the harshest place on Earth, love finds a way. This is the incredible true story of a family's journey to bring life into the world".

The film has been an exceptional success. It won an Academy Award (an 'Oscar') in 2006 for Best Documentary Feature, was awarded Best Documentary at the 2005 National Board of Review and was nominated for Best Documentary in 2005 by the Broadcast Film Critics Association. In terms of revenue it the most successful nature film in American motion picture history, taking US\$77.4m at the box office and US\$29.9m in VHS rentals (Rotten Tomatoes, 2007) and has its own Wikipedia entry (Wikipedia, 2007). It success gave a boost to the carton film Happy Feet with its rap-dancing Mumble (see http://www2.warnerbros.com/happyfeet/) and Christmas 2006 in the UK saw an explosion of penguin merchandise - I was even given a Happy Feet Advent Calendar from Marks \& Spencer with five penguin finger puppets as well as the more traditional 25 pieces of chocolate. The reasons for the success of March of the Penguins are no doubt several: the photography is phenomenal; the emperor penguin's story is extraordinary; the adults are elegant; the chicks are irredeemably cute as they look fluffy, feebly wave their little wings and learn to walk; the way in which the birds survive the Antarctic winter is awesome; the plaintive cries of mothers who lose their chicks in snow storms are heartrending. But one perhaps unexpected reason is that the film has been a great success among the Christian right.

For example, if one enters '"march of the penguins" Christian' into Google, at the time of writing (20 January 2007) one finds 173,000 hits. Top of these is a review of the film by Mari Helms (n.d.) on ChristianAnswers.Net, which describes itself as "a mega-site providing biblical answers to contemporary questions for all ages and nationalities with 40-thousand files" (ChristianAnswers.Net, 2007). After a fairly detailed summary of the subject matter of the film, and reassurance that viewers won't find much in the film to be objectionable (noting, for instance, under the sub-heading 'Sex/Nudity' that “The penguins mate during the film, but it is understood, not shown"), the review goes on to discuss the lessons that the film has to teach about love, perseverance, the existence of God and friendship/commraderie. An extended quote from the review [underlinings indicate hyperlinks to other pages on the ChristianAnswers.Net website] illustrates the presuppositions of the author: 
FRIENDSHIP/COMMRADERIE: All the penguins wait to start their journey until the last of them is out of the water, giving a sense of unity. As the penguins make their journey, they will all stop from time to time until one of them picks up the trail again, and then they all start moving. It is similar to what we are called to do in the body of Christ. 1 Corinthians 12:27-28 "Now you are the body of Christ, and each one of you is a part of it. And in the church God has appointed first of all apostles, second prophets, third teachers, then workers of miracles, also those having gifts of healing, those able to help others, those with gifts of administration, and those speaking in different kinds of tongues."

While the fathers are caring for their unhatched chicks and braving the harshest of weather, they all huddle together in a huge heap for warmth. The ones on the outside rotate, so they all have a turn in the middle. Philippians 2:2-4 "then make my joy complete by being like-minded, having the same love, being one in spirit and purpose. Do nothing out of selfish ambition or vain conceit, but in humility consider others better than yourselves. Each of you should look not only to your own interests, but also to the interests of others."

I was truly fascinated by the lives of these penguins, maybe because I felt we as humans could emulate much of it and be better followers of the gospel of Jesus Christ. They all worked together towards a common goal; there was no fighting, gossiping and disorder. There was apparent "love," cooperation and order. 1 Corinthians 12:25 "so that there should be no division in the body, but that its parts should have equal concern for each other."

I found the movie exciting and educational (but my three year old found it boring). What a great feeling it was to leave the theater without watcher's remorse (sitting through a movie that went against my value system or offended my Lord and Savior).

(Helms, n.d.)

In Barbour's framework, this quote manifests an integrated relationship between science and religion. The worldview is one in which it is straightforward to read from penguin behaviour to human behaviour though it is worth noting that the argument is neither entirely anthropomorphic (in which non-human behaviour is interpreted as if it was the behaviour of humans) nor one in which the natural world is seen as the source 
of instruction as to how humans should behave. Rather, it is scripture that has primacy; the natural world is then held up not so much as a model for us to imitate but as an illustration of how the natural world can manifest that which God wishes for humanity.

Such a reading of nature in March of the Penguins is facilitated by the wonderful photography which enables the viewer to read into the footage as much as (s)e reads from it. Indeed, Luc Jacquet has been quoted as saying "My intention was to tell the story in the most simple and profound way and to leave it open to any reading" (Miller, 2005). So I, with a $\mathrm{PhD}$ and post-doctoral research in evolutionary biology (though also a priest in the Church of England with a conventional, albeit non-fundamentalist, Christian faith), can see it as a manifestation of the extraordinary ability of natural selection over millions of years to enable an organism to survive and reproduce in the most inhospitable of environments while others see it as a clear manifestation of Intelligent Design:

To think that natural selection or even the penguins themselves could come up with the idea to migrate miles and miles multiple times each year without their partner or their offspring is a bit insulting to my intellect. How great is our God!

(Gold, 2005)

Such a conclusion is despite the fact that the film begins by talking about how Antarctica used to be covered in tropical forest before it drifted South and then says of the emperor penguins "For millions of years they have made their home on the darkest, driest, windiest and coldest continent on earth" and is despite the fact that the film relates that females aggressively compete for males and depicts the way in which mothers who have lost their chicks may attempt to steal other chicks. The film is also honest, to the chagrin of some conservatives, about the fact that most emperor penguins are faithful to their partners for only one season; in the jargon of ethologists (those who study animal behaviour) emperor penguins are serially monogamous, unlike, for example, swans who typically pair for life - though extra-pair copulations do occur in swans (Barash \& Lipton, 2001). However, such mentions are brief. As Richard Blake has pointed out:

"You get a sense of these animals - following their natural instincts - are really 
exercising virtue that for humans would be quite admirable," he said. "I could see it as a statement on monogamy or condemnation of gay marriage or whatever the current agenda is."

(Miller, 2005)

\section{And Tango Makes Three}

Blake's quote, with which the previous section ends, leads nicely onto a very different treatment of penguins (chinstrap penguins rather than emperor), namely that provided in an illustrated children's book And Tango Makes Three (Richardson \& Parnell, 2005). Like March of the Penguins, And Tango Makes Three has been widely acclaimed. In 2006 it was named an American Library Association Notable Children's Book. It received the Henry Bergh Award and the Gustavus Myer Outstanding Book Award. It was named a Nick Jr. Family Magazine Best Book of the Year, a Bank Street Best Book of the Year, a Cooperative Children's Book Council Choice, and a CBC/NCSS Notable Social Studies Trade Book. And Tango Makes Three was also a finalist for the 2006 Lambda Literary Award (Wikipedia, 2007b).

And Tango Makes Three tells the tale of a small colony of chinstrap penguins in Central Park Zoo in New York. As the book relates:

Every year at the very same time, the girl penguins start noticing the boy penguins. And the boy penguins start noticing the girls. When the right girl and the right boy find each other, they become a couple.

Two penguins in the penguin house were a little bit different. One was named Roy, and the other was named Silo. Roy and Silo were both boys. But they did everything together.

They bowed to each other. And walked together. They sang to each other. And swam together. Wherever Roy went, Silo went too.

They didn't spend much time with the girl penguins, and the girl penguins didn't spend much time with them. Instead, Roy and Silo wound their necks around each other. Their keeper Mr. Gramzay noticed the two penguins and thought to himself, "They must be in love." 
What happens next is that Roy and Silo build a nest but, of course, cannot produce an egg. There's a sad account of how Roy finds a rock and brings it to the nest; for day after day the two penguins alternate sitting on it and caring but, of course, nothing happens. They Mr Gramzay "found an egg that needed to be cared for and he brought it to Roy and Silo's nest". Switching to the scientific language absent from the book, incubation proceeds successfully, and:

Out came their very own baby! She had fuzzy white feathers and a funny black beak.

Now Roy and Silo were fathers. "We'll call her Tango," Mr. Gramzay decided, "because it takes two to make a Tango."

(Richardson \& Parnell, 2005, no page numbers)

The book ends soon afterwards and, throughout, it could not be more positive in its presentation of Roy and Silo. The drawings anthropomorphically show them surprised and disappointed when nothing happens to their rock despite their persistent incubation, and blissful when Tango emerges. The book closes with an authors' note, the first paragraph of which reads:

All of the events in this story are true. ... After years of living side by side in the Central Park Zoo, they [Roy and Silo] discovered each other in 1998 and they have been a couple ever since. Tango, their only chick, was born from an egg laid by another penguin couple named Betty and Porkey. That couple had often hatched their own eggs, but they had never been able to care for more than one at a time. In 2000, when Betty laid two fertile eggs, Rob Gramzay decided to give Roy, Silo, and one of those eggs a chance to become a family.

(Richardson \& Parnell, 2005, no page numbers)

So, we can rest assured that Roy and Silo, while gay, didn't rush into their relationship [like any sensible couple, they took their time]; they have been faithful to one another for years [no promiscuity here]; Tango wouldn't have survived unless Rob Gramzay had rescued her as an egg [perhaps an echo of the pro-life agenda]; Roy and Silo have been given their chance to become parents [mirroring the debate on reproductive rights in humans]; Tango is their only chick [the whole episode 
illustrates restraint].

Unsurprisingly, And Tango Makes Three has been controversial. At the time of writing (27 January 2007) it has 47 hits on Google News. Nearly all of these centre on rows about whether the book should be available in libraries. There have been a number of calls for it to be removed from the shelves, or placed in restricted areas, on the grounds that it promotes homosexuality. For example:

Shiloh resident Lilly Del Pinto felt upset when her five-year-old daughter brought the book home. She was reading it to her when she got to a point where the zoo keeper says Roy and Silo must be in love. Then she realised it was not quite the straightforward animal tale she had expected. 'That's when I ended the story,' she said. Now Del Pinto wants the book kept in a more mature section of the library or for parental permission to be sought for it to be taken out.

(Harris, 2006)

However, in a twist that connects with the attempts of certain Christian ministries to get gay people to go straight (Erzen, 2006), the arrival of Scrappy, a single chinstrap female from Sea World Zoo in San Diego, led to Silo moving out of his nest with Roy and in with Scrappy (Cohen, 2005). This has been widely discussed in blogs. For example:

So homosexuality exists in the natural world. Let's get over it. Homosexuality exists among humans (we are after all not disconnected from the natural world no matter what some Creationists might suggest otherwise), but the question is rather how we who are so inclined can live that out, at least as Christians, in a godward direction so as to grow in the virtues and bear good fruit, becoming more like Christ, showing forth in some way the character of G-d: faithful, forgiving, compassionate, steadfast, self-emptying.

(Christopher, 2005)

Unsurprisingly, Silo's recent sexual proclivity has been seized on by moral conservatives unhappy with And Tango Makes Three:

This book made me angry because it forced a questionable sexual practice on my children, passing it off as something as legitimate as their own family. It attempts to normalize something clearly abnormal. Penguins, like all other creatures, mate 
primarily for procreation. The fact that the keeper had to steal an egg from another couple to make a "family" shows that same-sex couples by themselves do not have what nature requires for them to conceive and bear children. Ironically, it was just announced that Silo has broken up with Roy and shacked up with Scrappy, a new penguin from the San Diego Zoo. Don't you just love those bi-coastal relationships? And the real shocker is that Scrappy is—gasp!-a female penguin. Silo has been proclaimed as the nation's first ex-gay penguin. Little doubt exists that they will need no intervention to produce a child.

Regardless, this book has been insidiously and deceitfully placed in libraries across America to re-educate young children to accept all families as valid, whether they have two mommies, two daddies, three daddies or three mommies and two daddies. It is deceptively normal and intentionally aimed at children whose primary concern should be Legos and dolls. They push the debate on homosexuality into the kindergarten when the only debate children that age should be forced to decide is crust or no crust on their sandwiches.

(Walden, 2005)

For readers wondering what happened next, as of December 2006 Silo was still with Scrappy but they had yet to produce an egg; Tango was now 6 years old and paired with Tazuni, another female; and Roy "has been seen alone, in a corner, staring at a wall” (GayPatriot, 2006).

\section{Possible ways forward when teaching school science}

As I hope is apparent, the intention of this article is not to argue that we should teach lots about penguins in school science, nor is the argument restricted to how we should teach animal behaviour or even biology. While it particularly easy to read the natural world in light of religious worldviews when the focus is on animal behavior, a religious worldview enables, indeed, often requires, the viewer to see all of life within its compass (cf. Hansson and Redfors (2006) who discuss the importance of students' religious views for their learning in cosmology).

The two penguin stories and their reception are discussed here to indicate how deeply the worldview that a person (whether author, scientist, high school student, worshipper) has can influence how they imagine the world (cf. the Blake quote at the 
heading of this paper which shows, of course, that Blake was able to make, what was for him, the border crossing from science to religion and back again). Dingwall and Aldridge (2006) point out that many 'blue chip' TV wildlife programmes do not challenge creationist accounts and may even implicitly endorse notions of intelligent design with their emphasis on how well organisms are designed for their environments and lifestyles.

A person can have more than one worldview and there are many worldviews other than religious ones but the religious worldview is a powerful and important one for many people. It provides a lens through which the world, including those aspects of the world that science focuses on, can be viewed. Much of the science education literature ignores the science/religion issue. However, a growing number of studies are trying to find effective ways of understanding the issues (e.g. Gauch, in press). More specifically, a number of studies have emphasised the value of using the evolution/creationism controversy as a way of showing how science works (Skehan \& Nelson, 2000; several contributors to Campbell \& Meyer, 2003).

Whether or not it is appropriate, or even legal, to teach students in science classes about the nature of religious knowledge as well as the nature of scientific knowledge is likely to vary from country to country (cf. Kawasaki, 1996; National Academy of Sciences, 1999), from time to time, from school to school, and from teacher to teacher within a school (Reiss, 2007). In the USA, in particular, teaching about religion is often held to be illegal in public (i.e. state-funded) schools on Constitutional grounds:

The Eleventh Circuit Court of Appeals has also ruled that a school can direct a teacher to refrain from discussing religion in classroom settings (Bishop v. Aronov, 1991), and the Supreme Court has stated that schools have a duty to make sure teachers do not inculcate religion (Lemon v. Kurtzman, 1971). The prohibition against an establishment of religion (as occurs with the teaching of creationism) in these situations outweighs the public school teachers' right to free speech.

(Moore, 2007, page 23)

However, USA history teachers, for example, can teach about religion so long as it is appropriate for an understanding of the subject and provided they do not attempt to argue for or against a particular religion. In the same way, it seems possible that the 
USA courts would permit teaching about religion in science lessons in similar circumstances. Ways of teaching in the USA in the science / religion area in science lessons are explored by several of the authors in Jones and Reiss (2007).

Perhaps the strongest argument for teaching anything about religion in a science class, whether at school, college or university, is if it helps students better to understand science. Martin (1994) put the point rather bluntly:

I will maintain that learning pseudoscience and the paranormal should be part of the goal of science education. The goal should not be to instil such beliefs in students but to get them to think critically about such beliefs. Science education, I will maintain, should not be narrowly conceived. The goal of science education should not be to get students to understand science but to be scientific; that is, to tend to think and act in a scientific manner in their daily lives. Learning to think critically about pseudoscientific and paranormal beliefs is part of being scientific.

(Martin, 1994, page 357)

Teaching about aspects of religion in science classes could potentially help students better understand the strengths and limitations of the ways in which science is undertaken, the nature of truth claims in science, and the importance of social contexts for science (cf. Gauld, 2005). However, there are also reasons to be cautious before teaching about aspects of religion in science classes (Reiss, 1992). For example, a science teacher may feel that they simply don't have the expertise to teach effectively about such matters, that these matters are better dealt with elsewhere in the curriculum, or that it is impossible to teach objectively about such matters so that one risks indoctrinating one's students either into or away from a religious faith (e.g. Mahner \& Bunge, 1996).

On the other hand, avoiding science / religion issues, when they are of relevance to students, may not only lead to a poorer understanding of the nature of science (cf. Cobern, 2000), it may increase the chance that science remains irrelevant for some students, unconnected to their worldview. At a time when growing numbers of students in industrialised countries say that they find school science to be boring and irrelevant (e.g. Schreiner, 2006), and drop it as soon as they can, this argument needs to be born in mind. In related vein, Mueller and Bentley (2007) argue that a more pluralistic approach to science education can help engage the diversity of 
students who are encountered by teachers in schools.

At the very least, science educators and teachers need to take account of religious worldviews if some students are better to understand the compass of scientific thinking and some of science's key conclusions, including the theory of evolution. Little is to be gained and much lost by ridiculing non-scientific worldviews. It is perfectly possible for a science teacher to be respectful of the positions that students hold, even if these are scientifically limited, indeed, to engage with these positions, while clearly and non-apologetically but sensitively helping students to understand the scientific worldview on a particular issue, whether biodiversity or otherwise.

\section{References}

Al-Hayani, F.A.: 2005, 'Islam and science: contradiction or concordance' Zygon, 40, $565-576$.

Ayala, F.J.: 2006, Darwin and Intelligent Design, Fortress Press, Minneapolis, MN.

Baker, S.: 2003, Bone of Contention: Is evolution true?, $3^{\text {rd }}$ edn, Biblical Creation Society, Rugby.

Barash, D.P. \& Lipton, J.E.: 2001, The Myth of Monogamy: Fidelity and Infidelity in Animals and People, W. H. Freeman, New York.

Barbour, I.G.: 1990, Religion in an Age of Science: The Gifford Lectures 1989-1991, volume 1, SCM, London.

Behe, M.J.: 1996, Darwin's Black Box: The biochemical challenge to evolution, Free Press, New York.

Blake, W.: 1810, Notebook on A Vision of the Last Judgement.

Brooke, J.H.: 1991, Science and Religion: Some historical perspectives, Cambridge University Press, Cambridge.

Campbell, J.A. \& Meyer, S.C. (eds): 2003, Darwinism, Design, and Public Evolution, Michigan State University Press, East Lansing, Michigan.

ChristianAnswers.Net: 2007, [Home page] http://christiananswers.net/ (last accessed 20 January 2007).

Christopher: 2005, 'Roy and Silo split', September 30 http://images.google.com/imgres? imgurl=http://static.flickr.com/29/48086572_c14a3ae584_m.jpg\&imgrefurl=htt 
p://regula.blogspot.com/2005 0901 regula_archive.html\&h $=157 \& w=240 \&$ sz $=21 \& \mathrm{hl}=$ en\&start=16\&tbnid=DgZPgd7DVtbKkM:\&tbnh=72\&tbnw=110\&prev $=/$ images $\% 3 \mathrm{Fq} \% 3 \mathrm{Dsilo} \% 2 \mathrm{Broy} \% 26$ svnum $\% 3 \mathrm{D} 10 \% 26 \mathrm{hl} \% 3 \mathrm{Den} \% 26 \mathrm{safe}$ \%3Doff $\% 26$ client $\% 3$ Dsafari $\% 26 \mathrm{rls} \% 3 \mathrm{Den} \% 26 \mathrm{sa} \% 3 \mathrm{DN}$ (last accessed 27 January 2007).

Cobern, W.W.: 2000, 'The nature of science and the role of knowledge and belief' Science \& Education, 9, 219-246.

Cohen, B.: 2005, 'New York's gay penguins split up (and one turns straight)' http://www.pinknews.co.uk/news/articles/2005-84.html (last accessed 27 January 2007).

Collins, F.S.: 2006, The Language of God: A scientist presents evidence for belief, Free Press, New York.

Dawkins, R.: 2006, The God Delusion, Bantam Press, London.

Dembski, W.A.: 1998, The Design Inference: Eliminating chance through small probabilities, Cambridge University Press, Cambridge.

Dembski, W.A.: 1999, Intelligent Design: The bridge between science \& technology, IVP Academic, Downers Grove, IL.

Dingwall, R. \& Aldridge, M.: 2006, 'Television wildlife programming as a source of poplar scientific information: a case study of evolution' Public Understanding of Science, 15, 131-152.

Edis. T.: 2007, An Illusion of Harmony: Science and religion in Islam, Prometheus Books, Amherst, NY.

Erzen, T.: 2006, Straight to Jesus: Sexual and Christian conversions in the ex-gay movement, University of California Press, Berkeley.

Gauch, H.G.Jr.: in press, 'Science, worldviews and education' Science \& Education.

Gauld, C.F.: 2005, 'Habits of mind, scholarship and decision making in science and religion' Science \& Education, 14, 291-308.

GayPatriot: 2006, 'Gay penguin book causes uproar in Charlotte', December 22 http:/gaypatriot.net/category/gay-pc-silliness/ (last accessed 27 January 2007).

Gold, J.: 2005, 'Does March of the Penguins support Intelligent Design theory?' http://www.christiantoday.com/article/does.march.of.the.penguins.support.intell igent.design.theory/4018.htm (last accessed 20 January 2007).

Good, R.G., Trowbridge, J.E., Demastes, S.S., Wandersee, J.H., Hafner, M.S. \& Cummins, C.L. (eds): 1992, Proceedings of the 1992 Evolution Education 
Research Conference Louisiana State University, Baton Rouge.

Gould, S.J.: 1999, Rocks of Ages: Science and religion in the fullness of life,

Ballantin, New York.

Hansson, L. \& Redfors, A.: 2006, 'Swedish upper secondary students' views of the origin and development of the Universe' Research in Science Education, 36, 355-379.

Harris, P.: 2006, 'Flap over a tale of gay penguins'

http://books.guardian.co.uk/news/articles/0,1951970,00.html (last accessed 27 January 2007).

Haught, J.F.: 1995, Science \& Religion: From conflict to conversation, Paulist Press, New York.

Hayward, A.: 1985, Creation and Evolution: The facts and fallacies, Triangle, London.

Helms, M.: n.d., 'Movie review: March of the Penguins' http://christiananswers.net/spotlight/movies/2005/marchofthepenguins2005.htm 1 (last accessed 20 January 2007).

Hick, J.: 1976/1985, Death and Eternal Life, Macmillan, Basingstoke.

Interacademy Panel on International Issues: 2006, IAP Statement on the Teaching of Evolution. Available at http://www.interacademies.net/Object.File/Master/6/150/Evolution \%20statement.pdf (last accessed 28 December 2006).

Jacquet, L.: 2006, March of the Penguins, National Geographic, Washington DC.

Johnson, P.E.: 1999, 'The wedge: breaking the modernist monopoly on science' Touchstone, 12(4), 18-24.

Jones, L. \& Reiss, M.J. (eds): 2007, Teaching about Scientific Origins: Taking account of creationism, Peter Lang, New York.

Kawasaki, K.: 1996, 'The concepts of science in Japanese and Western education' Science \& Education, 5, 1-20.

Kitcher, P.: 1983, Abusing Science: The case against creationism, Open University Press, Milton Keynes.

Lederman, N.G.: 2007, 'Nature of science: past, present, and future'. In: S.K. Abell \& N.G. Lederman (eds) Handbook of Research on Science Education, Lawrence Erlbaum, Mahwah, NJ, pp.831-879.

Mabud, A.: 1991, Theory of Evolution: An assessment from the Islamic point of view, 
Islamic Academy, Cambridge.

Mahner, M. \& Bunge, M.: 1996, 'Is religious education compatible with science education?' Science \& Education, 5, 101-123.

Martin, M.: 1994, 'Pseudoscience, the paranormal, and science education' Science \& Education, 3, 357-371.

Maynard Smith, J. \& Szathmary, E.: 2000, The Origins of Life: From the birth of life to the origin of language, Oxford University Press, Oxford

Miller, J.: 2005, 'March of the Conservatives: Penguin film as political fodder' http://www.nytimes.com/2005/09/13/science/13peng.html? $\underline{\mathrm{ex}}=1284264000 \& \mathrm{en}=36 \mathrm{effea} 48 \mathrm{de} 3 \mathrm{fa} 22 \& \mathrm{ei}=5088 \&$ partner $=\mathrm{rssnyt} \& \mathrm{emc}=\mathrm{rss}$ (last accessed 20 January 2007).

Miller, J.D., Scott, E.C. \& Okamoto, S.: 2006, 'Public acceptance of evolution’ Science, 313, 765-766.

Moore, R.: 2007, 'The history of the creationism/evolution controversy and likely future developments'. In: L. Jones \& M.J. Reiss (eds) Teaching about Scientific Origins: Taking account of creationism, Peter Lang, New York, pp11-29.

Mueller, M.P. \& Bentley, M.L.: 2007, 'Beyond the "decorated landscapes” of educational reform: towards landscapes of pluralism in science education' Science Education, 91, 321-338.

National Academy of Sciences: 1999, Science and Creationism: A view from the National Academy of Sciences, $2^{\text {nd }}$ edn, National Academy Press, Washington, DC.

Negus, M.R.: 2005, 'Islam and science'. In: C. Southgate (ed.) God, Humanity and the Cosmos, $2^{\text {nd }}$ edn revised and expanded as A Companion to the ScienceReligion Debate, T \& T Clark, London, pp.321-339.

Osborne, J., Collins, S., Ratcliffe, M., Millar, R. \& Duschl, R.: 2003, 'What “ideasabout-science" should be taught in school science? A Delphi study of the expert community' Journal of Research in Science Teaching, 40, 692-720.

Parker, G.E.: 2006, Creation: Facts of life - How real science reveals the hand of God, New Leaf Press, Los Angeles, CA.

Peacocke, A.: 2001, Paths from Science towards God: The end of all our exploring, Oneworld, Oxford.

Plimmer, I.: 1994, Telling Lies for God: Reason vs creationism, Random House, Milsons Point, NSW. 
Polkinghorne, J.: 1994, Science and Christian Belief: Theological reflections of a bottom-up thinker. The Gifford Lectures for 1993-4, SPCK, London.

Polkinghorne, J.: 2005, ‘The continuing interaction of science and religion' Zygon, 40, 43-50.

Ray, J.: 1691/2005, The Wisdom of God Manifested in the Works of the Creation, Ray Society, London.

Rees, M.J.: 2003, 'Other universes: a scientific perspective;. In N.A. Manson (ed) God and Design: The teleological argument and modern science, Routledge, London, pp.211-200.

Reiss, M.J.: 1992, 'How should science teachers teach the relationship between science and religion?' School Science Review, 74(267), 126-130.

Reiss, M.J.: 1993, 'The argument from design' Modern Churchman, 34, 105-110.

Reiss, M.J.: 2007, 'Teaching about origins in science - where now?'. In L. Jones \& M.J. Reiss (eds) Teaching about Scientific Origins: Taking account of creationism, Peter Lang, New York, pp199-210.

Reiss, M.J.: in press, 'Should science educators deal with the science/religion issue?' Studies in Science Education.

Richardson, J. \& Parnell,P.: 2005, And Tango Makes Three, Simon \& Schuster, New York.

Rotten Tomatoes: 2007, March of the Penguins http://en.wikipedia.org/wiki/March of the Penguins (accessed 20 January 2007).

Schreiner, C.: 2006, Exploring a ROSE-Garden: Norwegian Youth's Orientations Towards Science - Seen as Signs of Late Modern Identities, Faculty of Education, University of Oslo.

Selkirk, D.R. \& Burows F.J. (eds): 1987, Confronting Creationism: Defending Darwin, New South Wales University Press, Kensington, NSW.

Skehan, J.W. \& Nelson, C.E. (eds): 2000, The Creation Controversy \& The Science Classroom, NSTA Press, Arlington.

Southgate, C., Negus, M.R. \& Robinson, A.: 2005, 'Theology and evolutionary biology'. In: C. Southgate (ed.) God, Humanity and the Cosmos, $2^{\text {nd }}$ edn revised and expanded as A Companion to the Science-Religion Debate, T \& T Clark, London, pp.154-192.

Szerszynski, B.: 2005, 'Rethinking the secular: science, technology, and religion 
today’ Zygon, 40, 813-822.

Walden, S.R.: 2005, And Tango makes three?

http://www.homeschoolblogger.com/SteveWalden/31086/ (last accessed 27 January 2007).

Warner Independent Pictures: 2006, March of the Penguins: Official site http://wip.warnerbros.com/marchofthepenguins/ (last accessed 20 January 2007).

Watson, D.C.C.: 1975, The Great Brain Robbery, Henry E. Walter, Worthing.

Watts, F. (ed.): 1998, Science Meets Faith, SPCK, London.

Whitcomb, J.C. \& Morris, H.M.: 1961, Genesis Flood: The biblical record and its scientific implications, Presbyterian \& Reformed Publishing, Philadephia.

Wikipedia: 2007a, March of the Penguins http://en.wikipedia.org/wiki/March_of the Penguins (last accessed 20 January 2007).

Wikipedia: 2007b, And Tango Makes Three http://en.wikipedia.org/wiki/And_Tango_Makes_Three (last accessed 20 January 2007).

Williams, P.A.: 2001, Doing Without Adam and Eve: Sociobiology and original sin, Fortress Press, Minneapolis, MN. 